\title{
カメラフィードバックを用いた 自律移動マニピュレータの位置・速度制御
}

\author{
見 浪 護* 藤 原 直 史 ${ }^{* *}$ 柘 植 広 志***
Position·Velocity Control of Autonomous Mobile Manipulator with Camera Feedback

\section{Mamoru MINAMI Naofumi FUJIWARA Hiroshi TSUGE}

\begin{abstract}
It is more effective if a manipulator being set on a mobile robot can operate to load or unload while the mobile robot is moving. This paper presents the control method for the moving operations of an autonomous mobile manipulator (AMM). The AMM moving in the horizontal plane produces position errors in the plane and rotation error around the vertical axis, but does not produce the errors concerning with the other directions. Using this relation, we present a hybrid control system which consists of a camera feedback system and a kinematical one. We designed a control system for the AMM by introducing switching matrix to avoid the interactions of the two control systems. The experimental results using our AMM which consists of a power wheeled steering mobile robot and a PUMA-type manipulator show basic data of the control system.
\end{abstract}

Key Words : Autonomous, Mobile robot, Manipulator, CCD camera, Vision

\section{1. まえがき}

ロボット技術の発展は生産の効率を上げるための自動 化・無人化にとどまらず，人間にとって危険な作業の代 替といら面でも社会に貢献している. 半導体の生産工場 では人間が工場内のクリーンな環境にはいることが, 空 気の清浄度を劣化させ，結果として，歩留まりを下げ生 産効率を下げる原因になっている，このような環境下で 作業するロボットは人間の行ら作業のすべてを行うこと が望まれ，移動口ボットにマニピュレータを搭載したシ ステムが用いられている. 移動ロボットにマニピュレー タを搭載することは，搬送装置としてこれを用いる場合 に，載脱荷作業をするための地上側設備を減らす上でも 役立っている.

しかしながら現状の使用方法は, 移動動作と搭載され たマニピュレータの動作とを同時に行うことはないよう

原稿受付 1992 年 5 月 15 日

*(株)椿本チェイン

** 金沢大学

***（株)豊田自動織機媻作所
である、移動中にマニピュレータによる作業ができれば, より効率的である. 走行しつつ作業することは時間的な 効率を上げるらえでも, 停止及び発進に費やされるェネ ルギーを省くらえですメリットがある.

移動ロボットとマニピュレータの研究を結び付けよう とする試みはまだ余り多くないが，その中でも，移動口 ボットの運動学について同次変換行列を用いて表し, マ ニピュレータと同様に取り扱うことを試みた研究1 8), 多様な形態の移動ロボットを平面リンク機構として表現 し, さらに車輪の摩擦を含めた動力学についても議論し た研究がある4).

移動ロボットは非ホロノミックな拘束のもとに運動す ること，絶対精度が悪いこと，応答速度が遅いことなど マニピュレータとは異なる多くの問題点を持っている. このため移動ロボットの誘導に関して多くの研究がなさ れているが，目標コース上を安定して誘導できることを 証明したものはなかった. しかし，最近になり以下の三 つの仮定のもとに提案された誘導制御系の安定性が示さ れた 5),6)，(1）移動ロボットのダイナミクスを無視する こと, (2) 移動ロボットの目標速度・目標角速度は微 
分可能であること, (3) 移動ロボットの目標加速度・ 角加速度は有界であること，である．実際の移動ロボッ トは一般的に重くマニピュレータに較ぺて減速比が小さ いので，（1）の仮定は成り立たない，また，直線や円弧 の組み合わせで与えられた目標コース上を停止しないで 走行させる場合には，（2)，(3)の仮定も成り立たない. 従って実際の移動ロボットは目標コース上を正確に走行 していないと考えられる.このため自律移動マニピュレ ータの制御に関し，移動ロボットが自律型かそらでない かにかかわらず，目標コース上を走行していることを前 提にして車載マニピュレータのハンドの位置・姿勢制御 を行らことはできず, 移動ロボットの位置・速度などを フィードバックした制御系を構成すべきである．このよ

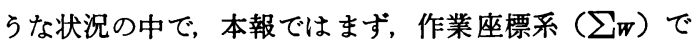
表されたハンドの目標位固・姿勢軌道とその微分を移動 ロボットに固定した移動座標系での記述に変換すること により，移動ロボットの位置・速度などを車載マニピュ レータの制御系にフィードバック於法について考え る.

次に自律型移動ロボットの特徵として，その位置・姿 勢の推定精度が悪く，定期的な補正を行う必要があるこ とがあげられる7 11). 推定䛊差は車載マニピュレータの ハンドの位置・姿勢誤差として現れ，ハンドの作業を害 する. この問題に対する解決方法としては, ハンド部に カメラを取り付け，作業対象物を写した画像情報より八 ンド部の偏差を検出し, 車載マニピュレータの制御系に フィードハッックする方法が考えられる. 水平面内を走行 する自律型移動ロボットでは, 水平面内の位置推定誤差 と鉛直軸回りの姿勢推定誤差は発生しやすいか;，他の方 向の誤差は発生しにくい. 従ってそのハンド部にカメラ センサーを取り付ければ, $\Sigma w$ の $x, y$ 軸回りの姿勢偏 差と $\boldsymbol{z}$ 軸方向の位置偏差が少ないことにより, カメラは 鉛直下方を向く.このため, カメラより得られる 2 次元 画像情報よりハンドの水平面内の位置誤差と鉛直軸回り の姿勢誤差が正確に測定できることになる.このような 自律型移動マニピュレータの特徵を考虑して， $\sum w$ の $x-y$ 平面内の位置誤差と $z$ 軸回りの姿勢誤差をカメラ フィード・ックにより補償し, その他の方向を運動学計 算により行うハイブリッド型の制御方法を提案する.

PUMA 型マニピュレータを 2 軸独立駆動型マニピュ レータに搭載した実験システムを構成し，提案した制御 系の基本的特性を確認したので報告する.

\section{2. マニピュレータの位是・资勢制御}

\section{1 マニピュレータの而娌学}

作業座標系 $\sum w$ の $x-y$ 平面(水平面と一致している)
内を 2 軸独立駆動型式の移動ロボットが走行している状 態を考える. 移動ロボットを代表するビークル座標系 $\Sigma_{V}$ の原点を左右駆動輪の中点に, $x$ 軸を右車輪方向に $y$ 軸を進行方向に定め, 移動ロボットに固定する. また， 車載マニピュレータのハンドにはハンド座標系 $\sum_{H}$ を設 定する. $\sum_{V}$ を基準にした $\sum_{H}$ の位置・姿勢ベクトル $\boldsymbol{v}_{\boldsymbol{r}}$ を，位置ベクトル $\boldsymbol{V}_{\boldsymbol{H} P}$ 姿勢ベクトル $\boldsymbol{V}_{\boldsymbol{H}}$ を用い $\tau{ }^{V} r_{H}=\left[{ }^{V} r_{H P}{ }^{T},{ }^{V} r_{H O}{ }^{T}\right]^{T}$ と表わす. 左上の添え字は基 準とする座標系を表し，右下の添え字は対象としている 座標系か又は変数の意味の補助として用いる. ${ }^{\boldsymbol{v}_{\boldsymbol{H}}}$ を実 現する関節角を $\boldsymbol{q}$ と表す. 6 自由度を持つマニピュレー タを想定し，特異姿勢でないことを仮定すると， $\boldsymbol{v}_{\boldsymbol{H}}$ と $\boldsymbol{q}$ の間には,

$$
\begin{gathered}
\boldsymbol{v}_{\boldsymbol{H}}=\boldsymbol{h}(\boldsymbol{q}) \\
\boldsymbol{q}=\boldsymbol{h}^{-1}\left(V_{\boldsymbol{r}_{H}}\right)
\end{gathered}
$$

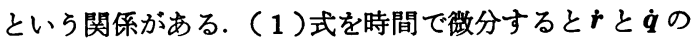
関係は,

$$
\begin{gathered}
v_{\dot{\boldsymbol{r}}_{H}}={ }^{V} J_{H}(\boldsymbol{q}) \dot{\boldsymbol{q}} \\
v_{J_{H}(\boldsymbol{q})}=\left(J_{i \jmath}\right), \quad J_{i \jmath}=\frac{\partial h_{\imath}(\boldsymbol{q})}{\partial q_{\jmath}} \\
i, j=1,2, \cdots, 6
\end{gathered}
$$

と表される. 各座標系と位固・姿勢ベクトルの関係を Fig. 1 に示す.

\section{2 移動ロボットの運動学}

移動ロボットは自らの位置・姿勢を左右駆動輪の走行 速度を測定することで算出し走行する自律型であること を想定する. $\sum w$ を基準にした各軸方向の速度 $\dot{X}_{V}, \dot{Y}_{V}$ と旋回角速度 $\dot{\theta}_{V}$ をまとめて ${ }^{W_{\boldsymbol{r}_{V}}}=\left[\dot{X}_{V}, \dot{Y}_{V}, 0,0,0, \dot{\theta}_{V}\right]^{T}$ $=\left[{ }^{W} \dot{r}_{V P}{ }^{T},{ }^{W} \dot{r}_{V O}{ }^{T}\right]^{T}$ と表し, 左右駆動輪の進行速度を $v=\left[v_{L}, v_{R}\right]^{T}$ と表し, 移動ロボットは二輪独立駆動型を 想定しているので, ${ }^{\boldsymbol{W}} \dot{\boldsymbol{r}}_{V}$ は,

$$
{ }^{W} \dot{\boldsymbol{r}}_{V}={ }^{W} \boldsymbol{J}_{V}\left(\theta_{V}\right) \boldsymbol{v}
$$

ただし

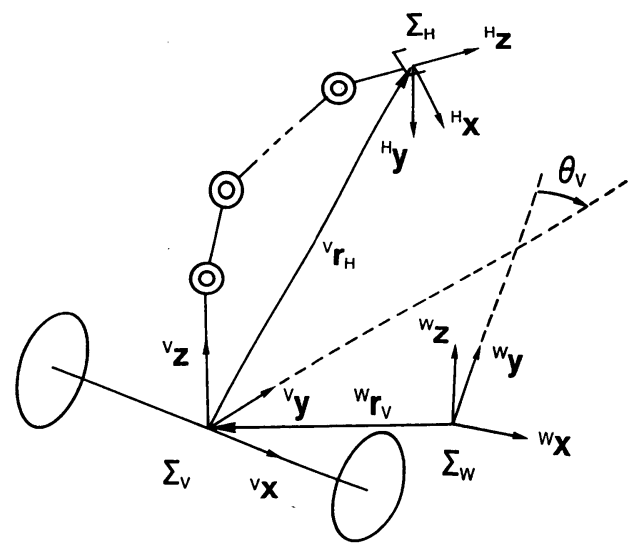

Fig. 1 Mobile manipulator 


$$
{ }^{W} \boldsymbol{J}_{V}\left(\theta_{V}\right)=\left[\begin{array}{cc}
-\left(\sin \theta_{V}\right) / 2 & -\left(\sin \theta_{V}\right) / 2 \\
\left(\cos \theta_{V}\right) / 2 & \left(\cos \theta_{V}\right) / 2 \\
0 & 0 \\
0 & 0 \\
0 & 0 \\
-1 / T & 1 / T
\end{array}\right]
$$

と表される．Tはトレッドである，ここで $\sum_{W}$ の $z$ 軸 ${ }^{W_{z}}$ と $\sum_{V}$ の $\boldsymbol{z}$ 軸 ${ }^{V} \boldsymbol{z}$ が一致していることに注意し， $\theta_{V}$ は $\sum w$ の $y$ 軸方向 ${ }^{W} \boldsymbol{y}$ を ${ }^{w_{\boldsymbol{z}}}$ 軸回りに回転させて ${ }^{v} \boldsymbol{y}$ と 一致させる角度と定義する. またその符号は $W_{z}$ 軸につ いて反時計回りの回転を正としている.

時刻 $t$ における移動ロボットの位置・姿勢 ${ }^{w} \boldsymbol{r}_{V}(\boldsymbol{t})$ は， ${ }^{W} \boldsymbol{r}_{V}(0)$ を初期值として，（5) 式の両辺を積分すること により

$$
{ }^{w} \boldsymbol{r}_{V}(t)={ }^{W} \boldsymbol{r}_{V}(0)+\int_{0}^{t}{ }^{w} \boldsymbol{J}_{V}\left(\theta_{V}\right) \boldsymbol{v} d u
$$

と表される.（5）式は車輪式移動ロボットの非ホロノミ ックな拘束条件であり，解析的に積分して幾何学的な拘 束にすることはできない，従って，以下に述べる近似を 行い, 積分する. 制御周期 $\tau$ を微少時間とし時刻 $(i-1) \tau$ より $\tau$ 秒間 $v_{R}, v_{L}$ をサンプルホールドした值を $v_{R}{ }^{i}$ ， $v_{L}{ }^{\imath}$ と表し, これらを用いて, 時刻 $\boldsymbol{i} \tau$ における移動口ボ ットの位置・姿勢 ${ }^{W} \boldsymbol{r}_{V}{ }^{i}$ の推定值 ${ }^{w} \hat{\boldsymbol{r}}_{V}{ }^{i}$ は,

$$
\begin{gathered}
{ }^{W} \hat{\boldsymbol{r}}_{V}^{i}={ }^{W} \hat{\boldsymbol{r}}_{V}^{i-1}+\Delta \hat{\boldsymbol{r}}^{i} \\
\Delta \hat{\boldsymbol{r}}^{i}=\left[\begin{array}{c}
-v^{i} \tau \sin \left(\theta_{V}^{i-1}+\Delta \theta_{V}^{i} / 2\right) \\
v^{i} \tau \cos \left(\theta_{V}^{i-1}+\Delta \theta_{V}^{i} / 2\right) \\
0 \\
0 \\
0 \\
\Delta \theta_{V}^{i}
\end{array}\right] \\
\boldsymbol{v}^{i}=\left(\boldsymbol{v}_{R}^{i}+\boldsymbol{v}_{L}^{i}\right) / 2, \Delta \theta_{V}^{i}=\left(\boldsymbol{v}_{R}^{i}-\boldsymbol{v}_{L}^{i}\right) \tau / T
\end{gathered}
$$

と近似的に求められる ${ }^{3), 12)}$. ここで，(8)式には(9)式 の近似誤差, 路面の凹凸による䛊差, 車輸のスリップに よる誤差等が累積されており，これを明示する意味で変 数にへを付記した. しかし以下では簡単のため（8)式 で得られた推定值を ${ }^{W} \boldsymbol{r}_{V}{ }^{\imath}$ と表す。この推定方法は何ら かの補正手段を用いて，誤差が許容範囲を越えないよう に注意する必要があり，その補正方法は種々提案されて いる7 11). また，添え字 $\boldsymbol{i}$ は以後の議論では意味を持た ないので省略することにする.

\section{3. 移動マニピュレータの目標軌道}

移動ロボットの走行を考慮して車載マニピュレータの ハンドの位置・姿勢を制御する方法について考える. $\sum W$ で表された目標軌道 ${ }^{W} \boldsymbol{r}_{H d}=\left[{ }^{W} \boldsymbol{r}_{H P d}{ }^{T},{ }^{W} \boldsymbol{r}_{H O d}{ }^{T}\right]^{T}$ と その微分 ${ }^{W} \dot{\boldsymbol{r}}_{H d}$ が与えられている場合を考光， ${ }^{W} \boldsymbol{r}_{H P d}$ と ${ }^{W} \boldsymbol{r}_{H O d}$ をそれぞれ目標位置・姿勢軌道と呼ぶことにす る. 移動ロボットに固定された座標系 $\Sigma_{V}$ で表された八

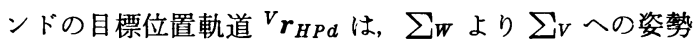
変換行列を ${ }^{W} \boldsymbol{R}_{V}$ とすると, 次式を満たさなければなら ない.

$$
{ }^{W} \boldsymbol{r}_{H P d}={ }^{W} \boldsymbol{r}_{V P}+{ }^{W} \boldsymbol{R}_{V}{ }^{V} \boldsymbol{r}_{H P d}
$$

移動ロボットの走行に伴い変化する ${ }^{W} \boldsymbol{R}_{V},{ }^{W} \boldsymbol{r}_{V P}$ に応 じて ${ }^{V} \boldsymbol{r}_{H P d}$ が上式を満たしつつ変化すれば，目標位置 軌道 ${ }^{W} \boldsymbol{r}_{H P d}$ は実現される.これを微分すると，

$$
{ }^{W} \dot{\boldsymbol{r}}_{H P d}={ }^{W} \dot{\boldsymbol{r}}_{V P}+{ }^{W} \dot{\boldsymbol{R}}_{V}{ }^{V} \boldsymbol{r}_{H P d}+{ }^{W} \boldsymbol{R}_{V}{ }^{V} \dot{\boldsymbol{r}}_{H P d}
$$

が得られる. ここで ${ }^{W} \dot{\boldsymbol{R}}_{V}$ と ${ }^{W} \dot{\boldsymbol{r}}_{V O}$ は, ${ }^{W} \dot{\boldsymbol{R}}_{V}={ }^{W} \dot{\boldsymbol{r}}_{V O} \times$ ${ }^{W} \boldsymbol{R}_{V}$ と関係づけられる. ただしメは外積を表す. 走行 している移動マニピュレータが， ${ }^{W} \boldsymbol{r}_{H P d},{ }^{W} \boldsymbol{r}_{H P d}$ を実現 するためには ${ }^{\boldsymbol{r}_{H P d},}{ }^{V} \dot{\boldsymbol{r}}_{H P d}$ は, (11), (12) 式より

$$
\begin{gathered}
{ }^{V} \boldsymbol{r}_{H P d}={ }^{W} \boldsymbol{R}_{V}{ }^{-1}\left({ }^{W} \boldsymbol{r}_{H P d}-{ }^{W} \boldsymbol{r}_{V P}\right) \\
{ }^{V} \dot{\boldsymbol{r}}_{H P d}={ }^{W} \boldsymbol{R}_{V}{ }^{-1}\left({ }^{W} \dot{\boldsymbol{r}}_{H P d}-{ }^{W} \dot{\boldsymbol{R}}_{V}{ }^{V} \boldsymbol{r}_{H P d}-{ }^{W} \dot{\boldsymbol{r}}_{V P}\right)
\end{gathered}
$$

を満たす必要があることがわかる．以上で $\sum_{W}$ で表さ れたハンドの目標位置軌道 ${ }^{W} \boldsymbol{r}_{H P d}$ とその微分 ${ }^{W} \dot{\boldsymbol{r}}_{H P d}$ が 移動する座標系 $\Sigma_{V}$ を基準にしたものに変換された。

次に目標姿勢軌道 ${ }^{W} \boldsymbol{r}_{H O d}$ とその微分 ${ }^{{ }^{W}} \dot{\boldsymbol{r}}_{H O d}$ を変換す る. ハンドの姿勢を表わす $3 \times 3$ 行列 $\boldsymbol{R}$ は, 姿勢 $\boldsymbol{r}_{0}$ の 定義に従って定まる関数 $\boldsymbol{f}$ により $\boldsymbol{R}=\boldsymbol{f}\left(\boldsymbol{r}_{O}\right)$ と表わさ れる. $\sum_{W}$ で表されたハンドの姿勢 ${ }^{W} \boldsymbol{R}_{H}$ が ${ }^{W} \boldsymbol{R}_{H}=$ ${ }^{W} \boldsymbol{R}_{V}{ }^{V} \boldsymbol{R}_{H}$ であることを考えると， $\Sigma_{V}$ で表されたハン ドの目標姿勢軌道は,

$$
{ }^{\boldsymbol{r}_{H O d}}=\boldsymbol{f}^{-1}\left({ }^{W} \boldsymbol{R}_{V}^{-1} \boldsymbol{f}\left({ }^{W} \boldsymbol{r}_{H O d}\right)\right)
$$

と求められる。 ${ }^{W} \dot{\boldsymbol{r}}_{H O d}$ と ${ }^{v} \dot{\boldsymbol{r}}_{H O d}$ の間には, ${ }^{W} \boldsymbol{T}_{H}{ }^{W} \dot{\boldsymbol{r}}_{H O d}$ $={ }^{W} \dot{\boldsymbol{r}}_{V O}+{ }^{W} \boldsymbol{R}_{V}{ }^{V} \boldsymbol{T}_{H}{ }^{V} \dot{\boldsymbol{r}}_{H O d}$ という関係がある. これより，

$$
{ }^{V_{\boldsymbol{r}_{H O d}}}=\left({ }^{W} \boldsymbol{R}_{V}{ }^{V} \boldsymbol{T}_{H}\right)^{-1}\left({ }^{W} \boldsymbol{T}_{H}{ }^{W} \dot{\boldsymbol{r}}_{H O d}-{ }^{W} \dot{\boldsymbol{r}}_{V O}\right)
$$

と変換される. ここで ${ }^{v} \boldsymbol{T}_{H}$ は ${ }^{\boldsymbol{r}_{H O d}}$ を $\Sigma_{V}$ の各軸回 りの角速度ベクトルに変換する $3 \times 3$ 行列であり, ${ }^{W} \boldsymbol{T}_{H}$ は ${ }^{W} \dot{\boldsymbol{r}}_{H O d}$ を $\sum w$ で表わされた角速度に変換する行列で ある・

以上で $\Sigma_{V}$ で表されたハンドの目標位置・姿勢軌道 ${ }^{V} \boldsymbol{r}_{H d}=\left[{ }^{V} \boldsymbol{r}_{H P d}{ }^{T},{ }^{V} \boldsymbol{r}_{H O d}{ }^{T}\right]^{T}$ とその微分 ${ }^{V} \dot{\boldsymbol{r}}_{H d}=\left[{ }^{V} \dot{\boldsymbol{r}}_{H P d^{T}}{ }^{T}\right.$, $\left.V \dot{r}_{H O d}\right]^{T}$ が求められた。

\section{4. 移動マニピューレータの制御則}

前節にて求めた ${ }^{v} \boldsymbol{r}_{H d},{ }^{v} \dot{\boldsymbol{r}}_{H d}$ を実現する関節角 $\boldsymbol{q}_{d}$ と 関節角速度 $\dot{\boldsymbol{q}}_{d}$ は, (2), (3) 式を用いて

$$
\begin{gathered}
\boldsymbol{q}_{d}=\boldsymbol{h}^{-1}\left({ }^{V} \boldsymbol{r}_{H d}\right) \\
\dot{\boldsymbol{q}}_{d}={ }^{V} \boldsymbol{J}_{H}{ }^{-1}(\boldsymbol{q})^{V} \dot{\boldsymbol{r}}_{H d}
\end{gathered}
$$

と定まる．これらをもとに，次節で述べるサーボ系へ与 える速度指示電圧を次式で求める.

$$
\boldsymbol{V}=\boldsymbol{K}_{1}\left(\boldsymbol{q}_{d}-\boldsymbol{q}\right)+\boldsymbol{K}_{2} \dot{\boldsymbol{q}}_{d}
$$

ここで $\boldsymbol{q}$ は実測された関節角である. 右辺第 2 項は, (14), (16), (18)式より目標軌道の微分であるフィードフ オワードと移動ロボットの走行速度のフィードバックを 


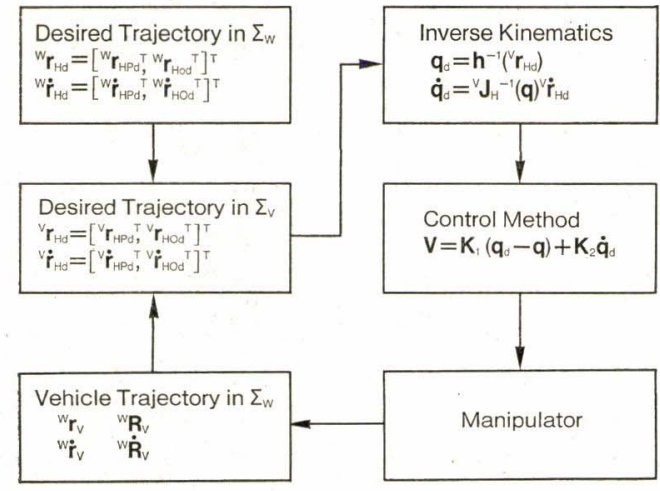

Fig. 2 Control block diagram of position and velocity

含んでいる. この制御系のブロック線図を Fig. 2 に示 于.

\section{5. 実験}

\section{1 ハードウェア構成}

Fig. 3 に, 実験に使用した PUMA 型マニピュレータ のリンク構成と，設定 したリンク座標系及び $\Sigma_{v}, \Sigma_{W}$

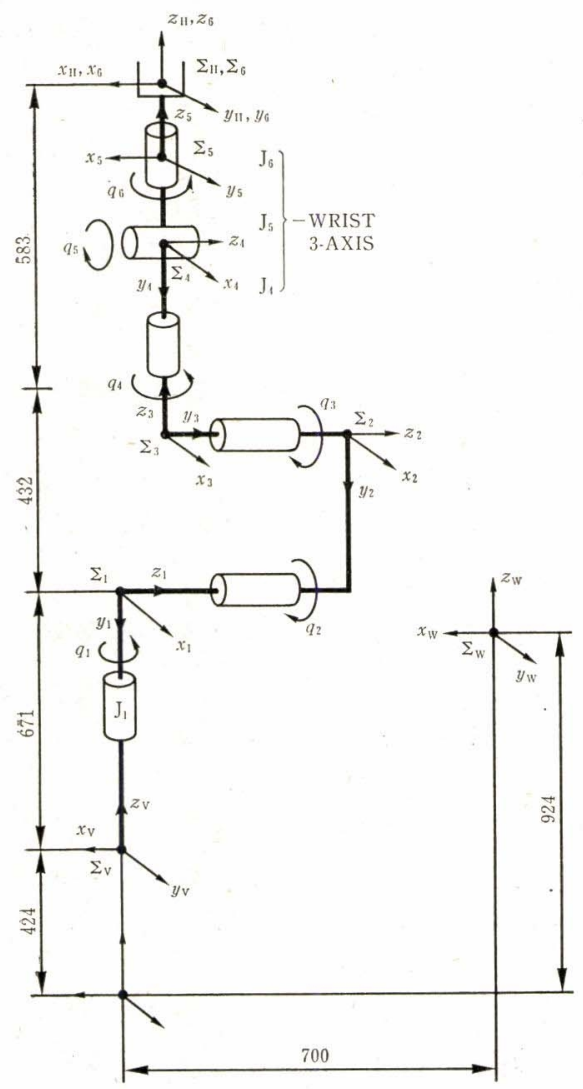

Fig. 3 Manipulator and link frames

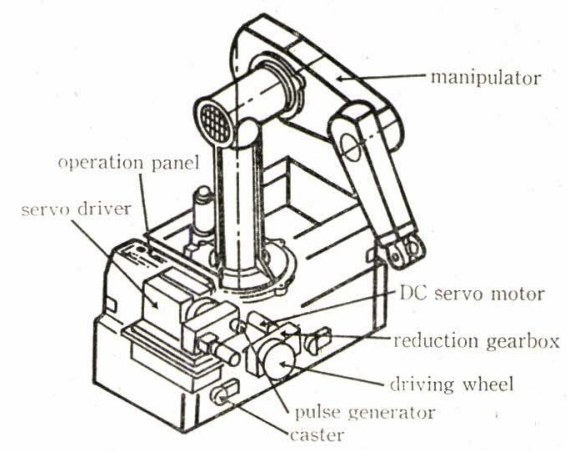

Fig. 4 Experiment system

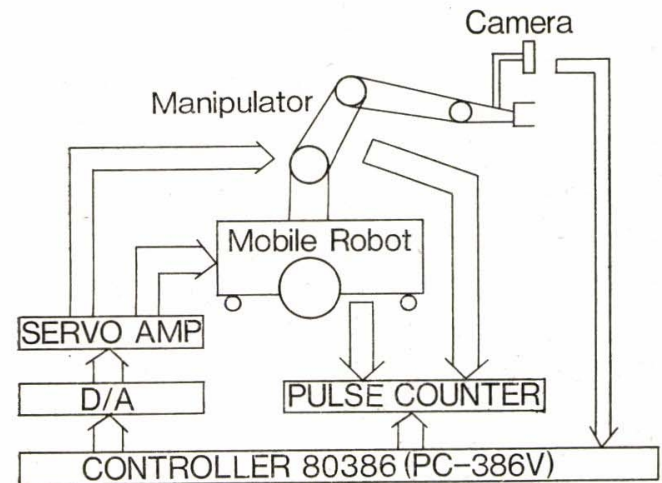

Fig. 5 Block diagram of the experiment system

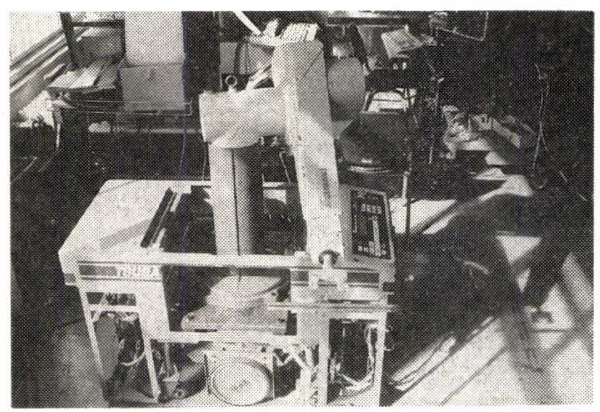

Fig. 6 Photograph of the autonomous mobile manipulator

Table 1 Specifications of the mobile robot

\begin{tabular}{|l|l|}
\hline Dimensions & $550 \mathrm{~W} \times 1140 \mathrm{~L} \times 702 \mathrm{H}[\mathrm{mm}]$ \\
\hline Weight & $173[\mathrm{kgf}]$ \\
\hline Payload & $100[\mathrm{kgf}]$ \\
\hline Max. Speed & $40[\mathrm{~m} / \mathrm{min}]$ \\
\hline Motor & DC Servo Motor $90[\mathrm{~W}] \times 2$ \\
\hline Reduction Ratio & $1 / 52$ \\
\hline Wheel Diameter & $237[\mathrm{~mm}]$ \\
\hline Tread & $470[\mathrm{~mm}]$ \\
\hline
\end{tabular}


を示す.また，Fig. 4 に全体の構成図を，Fig. 5 にコ ントローラを含めた実験システムの構成図を示す.CPU は80386 であり，制御周期は $35 \mathrm{~ms}$ である. Fig. 6 に 実験システムの写真を, Table 1 亿移動ロボットの仕様 を示した. マニピュレータの関節及び移動ロボットの左 右車輪にはパルスカウンタが装着され，関節角・回転角 が測定される.（19）式にて算出された指示電圧は D/A コンバータを介してサーボアンプに出力され，すべての 回転軸は DC モータにより駆動される．搭載したマニピ ニレータは, 川崎重工業 (株) 製 PH 560 である. 重量 は $95 \mathrm{kgf}$, 脚をのばした基本姿勢での全高は $1686 \mathrm{~mm}$ であり，移動ロボットに搭載したときの床から手先まで の高さは $2110 \mathrm{~mm}$ である.

\section{2 位貫・姿勢偏差の算出}

ここで次節の実験において使用する $\sum w$ に対する八 ンドの位置・姿勢偏差の算出方法を示して扣く． $\sum_{W}$ と ハンド座標系 $\Sigma_{H}$ の関係を表す 同次変換行列を ${ }^{W} \boldsymbol{H}_{H}$, 目標位置・姿勢を ${ }^{W} \boldsymbol{H}_{H d}$ とし，それらの列ベクトルを

$$
\begin{aligned}
& { }^{w} \boldsymbol{H}_{H}=\left[\begin{array}{cccc}
W_{n} & w_{o} & { }^{w} \boldsymbol{a} & { }^{w} r_{H P} \\
0 & 0 & 0 & 1
\end{array}\right] \\
& { }^{W} \boldsymbol{H}_{H d}=\left[\begin{array}{cccc}
W^{W} \boldsymbol{n}_{d} & { }^{W} \boldsymbol{o}_{d} & { }^{W} \boldsymbol{a}_{d} & { }^{W} \boldsymbol{r}_{H P d} \\
0 & 0 & 0 & 1
\end{array}\right]
\end{aligned}
$$

と定義すると, 位置・姿勢偏差 ${ }^{W} \boldsymbol{e}$ は

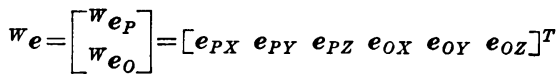

$$
\begin{aligned}
& =\left[\begin{array}{l}
{ }^{W} \boldsymbol{r}_{H P d}-{ }^{W} \boldsymbol{r}_{H P} \\
\left({ }^{W} \boldsymbol{n}_{d} \times{ }^{W} \boldsymbol{n}+{ }^{W} \boldsymbol{o}_{d} \times{ }^{W} \boldsymbol{o}+{ }^{W} \boldsymbol{a}_{d} \times{ }^{W} \boldsymbol{a}\right) / 2
\end{array}\right]
\end{aligned}
$$

と求められる ${ }^{13)}$.

\section{3 位置・姿勢制御実験}

3.4 章で述べた制御系が正しく動作することを確認す るために以下の実験を考える，まず，移動口ボットが走 行中に, Fig. 3 に示す $\sum_{W}$ の原点にハンドの位置・姿 勢を静止させる実験を行った．Fig.7（a）に初期位置・ 姿勢と走行方向を示す. 時刻 $0 \mathrm{~s}$ に移動口ボットに対し て $\sum_{w}$ の $y$ 軸方向にステップ速度入力を与え $(40 \mathrm{~mm} / \mathrm{s}$, $80 \mathrm{~mm} / \mathrm{s}$ )，一定速度で直線走行させた後，時刻 $4 \mathrm{~s}$ 江再 び停止させた，この間ハンドの位置・姿勢を維持するよ らに制御を行いその結果を(22) 式により観測する.

各関節の比例制御のみの場合について調べるため, $\boldsymbol{K}_{1}=\operatorname{diag}(10,10,10,10,10,10)[\mathrm{Volt} / \mathrm{rad}], \boldsymbol{K}_{2}=$ $\operatorname{diag}(0,0,0,0 ， 0 ， 0)[\mathrm{Volt} /(\mathrm{rad} / \mathrm{s})]$ と設定した. ゲイン $K_{1}$ は次のような予備実験を行って決定した. $K_{1}$ を増加させてゆくと, 10 [Volt $/ \mathrm{rad}]$ を越えた時点でマ ニピュレータの第一軸が不安定になった．このため全軸 について安定な範囲で制御実験を行らため, 10 [Volt/ rad] と定めた。 また，マニピュレータの関節はすべて

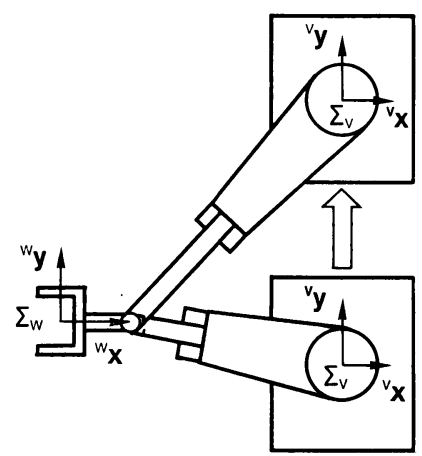

Fig. 7(a) Manipulator during straight traveling
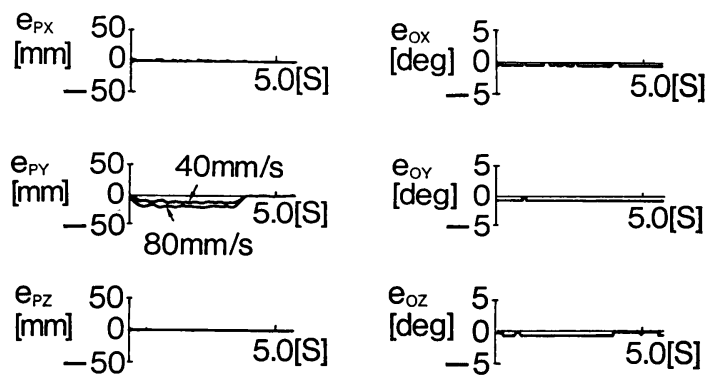

Fig. 7(b) Position and orientation errors (without velocity feedback)
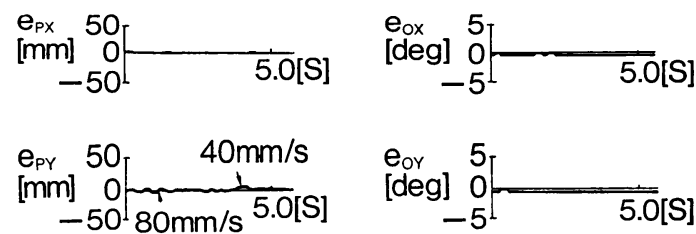

[mm] 50 $\mathrm{mm}] \underset{-50}{0} \quad 5.0[\mathrm{~S}]$

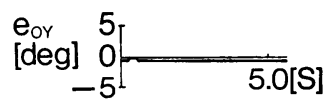

Fig. 7(c), Position and orientation errors (with velocity feedback)

1 Volt の電圧に対し $0.5 \mathrm{rad} / \mathrm{s}$ で回転するよらに調節さ れている. 実験結果を Fig. 7(b) に示す. $e_{P Y}$ に定常 偏差が移動ロボットの走行速度に比例している. $e_{P Y}$ の みに偏差があるのは，移動ロボットの走行方向が $\Sigma w$ の $y$ 軸方向と一致していたからである.

次に他の条件はそのままで $\boldsymbol{K}_{2}=\operatorname{diag}(2,2,2,2,2,2)$ と設定し速度フィードベックを付加した．結果を Fig. 7 （c）に示す. 少し振動的であるが定常偏差は減少して いる.

以上の実験を移動ロボットがスピンターン走行 (0.9 $\mathrm{rad} / \mathrm{s}, 1.8 \mathrm{rad} / \mathrm{s})$ をする場合について繰り返した．初期 位㯰・姿勢とスピンの方向を Fig. 8(a) 飞，結果を Fig. 8(b), (c) に示す. スピンターンにより $e_{P Y}$ と $e_{O Z}$ に 


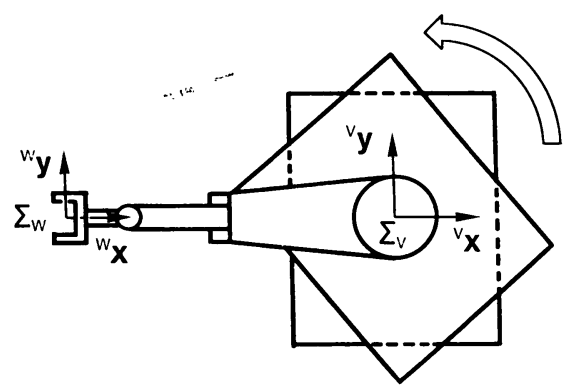

Fig. 8(a) Manipulator during spin traveling

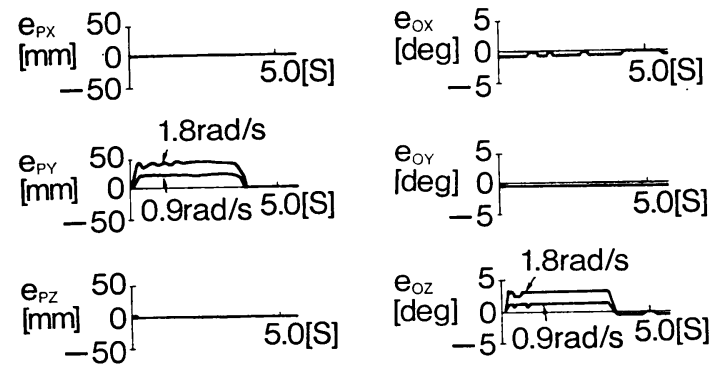

Fig. 8(b) Position and orientation errors (without velocity feed:ack)

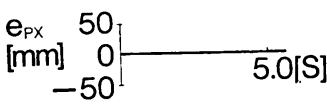

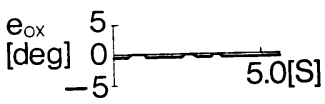

$e_{P Y} 50,1.8 \mathrm{rad} / \mathrm{s}$ [mm] 0 mo $0.9 \mathrm{rad} / \mathrm{s} 5.0[\mathrm{~s}]$

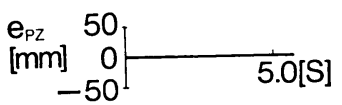

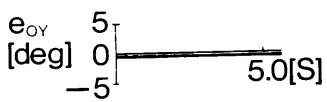

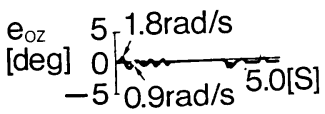

Fig. 8(c) Position and orientation errors (with velocity feedback)

定常偏差が発生し, 移動ロボットの㳬回各速度のフィー ドハックを施すことにより減少している．以上の実験に より移動ロボットとマニピュレータの間及びマニピュレ 一タのリンク間の動力学的干涉や非線形性が，本報の実 験条件に拗いては少なく，本手法の有効性が確認できた

\section{6. 車載マニピュレータによる移動ロボット の位置・姿勢推定誤差の補償}

\section{1 移動ロボットの位置・姿勢推定誤差の影響}

マニピュレータの制御式 (19) 式中の $\boldsymbol{q}_{d}, \dot{\boldsymbol{q}}_{d}$ は，(13), (14) 式及び (15), (16) 式より得られた ${ }^{{ }} \boldsymbol{r}_{H d},{ }^{{ }_{\boldsymbol{r}}} \dot{ }_{H d}$ を 用い，(17)，(18）式により算出されたものであり, 誤差 を含んだ移動ロボットの位置・姿勢 ${ }^{W} \boldsymbol{r}_{V P},{ }^{W} \boldsymbol{R}_{V}$ をもと に算出されている．従って（22）式は $\sum w$ 上の偏差を正

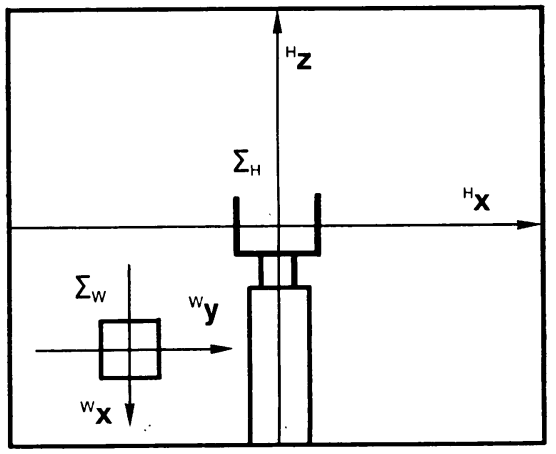

Fig. 9 Relation of work frame and hand frame

確に算出することはできなく（8）式により累積された 誤差に応じホハンドの誤差が残る. 移動走行中の載脱荷 作業に㧊いて，この誤差に起因するハンドの位置・姿勢 誤差以外は前章にて補償できることが確認されているの で，以下に推測演算誤差を車載マニピュレータで取り除 くことを考える.この䛊差をマニピュレータで補償する ためには， $\sum_{W} て ゙$ 表されたハンドの位置・姿勢䛊差を測 定する必要がある。また移動口ボットの動きは既知でな いため, そのフィードバックはリアルタイム制御系に組 み込まなければならない。

\section{2 カメラフィードバック制御系と位置・姿勢制御 系の協調}

$\sum w$ に対するハンドの位置・姿勢誤差 ${ }^{w} \delta \boldsymbol{x}$ は， $\sum w$ に対する位置・姿勢が明かな作業対象物を，ハンドに取 り付けられたカメラで観測することで検出される．Fig. 9 は作業対象物が $\sum_{W}$ の原点に置かれている時に, $\sum w$ の $x, y$ 軸の方向に位置偏差が発生している様子を示す. W $\delta \boldsymbol{x}$ に比例した力またはトルクをハンド部に発生させ る関節トルクを求めこれをフィードバックすることで W $\delta \boldsymbol{x}$ をなくす制御系は既に提案され，重力補償とダン ピングを付加することでその安定性も示されている ${ }^{15)}$.

しかし，現実的には ${ }^{W} \delta \boldsymbol{x}$ のすべての要素を観測できる センサーはなく，また逆に $\sum w$ のすべての座標軸につ いての位置・姿勢偏差をフィードバックする必要がない 場合もある. 本報で考えている移動マニピュレータでは 移動口ボットの移動は水平面内に限られること, 路面の 凹凸・リンクや減速機のたわみを無視できること，重力 による影響は既に補償されていることを仮定すれば水平 面内の位置誤差と鉛直軸回りの姿勢誤差は発生しやすい が，その他の方向の誤差は発生しにくい，従ってその八 ンド部にカメラセンサーを取り付ければ, $\sum w$ の $x, y$ 軸 回りの姿勢偏差と $z$ 軸方向の位置偏差が少ないことによ りカメラセンサーは鉛直下方を向く.このためカメラか らの 2 次元画像情報よりハンドの水平面内の位置誤差と 


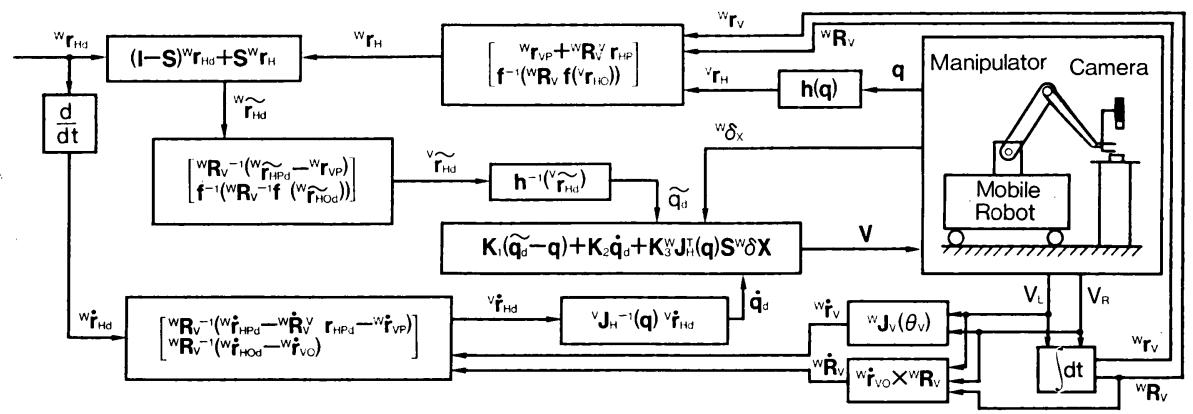

Fig. 10(a) Block diagram of compensation control of estimated errors

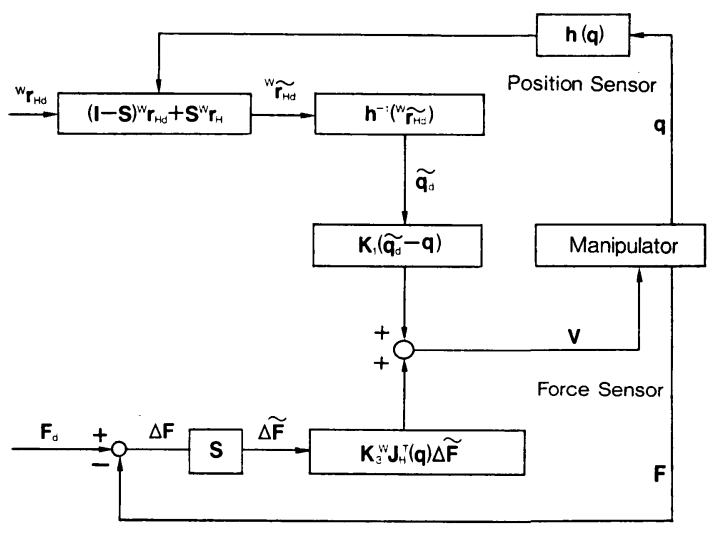

Fig. 10(b) Simplified and arranged control system

鉛直軸回りの姿勢誤差が正確に測定できることになる. 以上の関係を利用し以下に述ベる移動マニピュレータの 制御系を提案する.

作業座標系で表されたハンドの位置・姿勢の中でカメ ラフィードバックにより制御する方向と, 運動学計算に より制御する方向を分けるために新たな目標位置・姿勢 ${ }^{w} \tilde{r}_{H d}$ を ${ }^{w} \boldsymbol{r}_{H d}$ と ${ }^{w} \boldsymbol{r}_{H}$ を用いて，

$$
{ }^{W} \tilde{\boldsymbol{r}}_{H d}=\left[\begin{array}{c}
W \tilde{\boldsymbol{r}}_{H P d} \\
{ }^{W} \tilde{\boldsymbol{r}}_{H O d}
\end{array}\right]=(\boldsymbol{I}-\boldsymbol{S})^{W} \boldsymbol{r}_{H d}+\boldsymbol{S}^{W} \boldsymbol{r}_{H}
$$

と定める. I は単位行列であり， $\boldsymbol{S}$ はカメラフィードバ ックによる制御を行う $\sum_{W}$ の方向に対応する対角要素 を 1 としその他をすべて 0 とするスイッチング行列であ る.（23）式はカメラフィードバックで制御する方向に は，ハンドの現在の位置・姿勢をそのまま目標值として 与えることを意味している. これと (13) 式より， $\Sigma_{V}$ で 表された新たな目標値は,

$$
{ }^{V} \tilde{\boldsymbol{r}}_{H P d}={ }^{W} \boldsymbol{R}_{V}^{-1}\left({ }^{W} \tilde{\boldsymbol{r}}_{H P d}-{ }^{W} \boldsymbol{r}_{V P}\right)
$$

及び，(15)式より，

$$
{ }^{V} \tilde{\boldsymbol{r}}_{H O d}=\boldsymbol{f}^{-1}\left({ }^{W} \boldsymbol{R}_{V}{ }^{-1} \boldsymbol{f}\left({ }^{W} \tilde{\boldsymbol{r}}_{H O d}\right)\right)
$$

と求められる. 以上により ${ }^{W} \tilde{\boldsymbol{r}}_{H d}$ は ${ }^{V} \tilde{\boldsymbol{r}}_{H d}=\left[{ }^{V} \tilde{\boldsymbol{r}}_{H P d}{ }^{T}\right.$, $\left.V \tilde{\boldsymbol{r}}_{H O d^{T}}\right]^{T}$ に変換される. この結果を(2) 式に代入する ことにより $\tilde{\boldsymbol{q}}_{d}$ を求める. $\tilde{\boldsymbol{q}}_{d}$ は $\boldsymbol{S}$ の対角要素が 1 であ
る $\sum w$ 方向にはハンドを動かさない関節角度の指令值 である.カメラフィードバックによる制御を(19)式の 制御則に付加すると，

$$
\boldsymbol{V}=\boldsymbol{K}_{1}\left(\tilde{\boldsymbol{q}}_{d}-\boldsymbol{q}\right)+\boldsymbol{K}_{2} \dot{\boldsymbol{q}}_{d}+\boldsymbol{K}_{3}{ }^{W} \boldsymbol{J}_{H}{ }^{T}(\boldsymbol{q}) \boldsymbol{S}^{W} \delta \boldsymbol{x}
$$
たたし，

$$
{ }^{W} \boldsymbol{J}_{H}=\left[\begin{array}{cc}
{ }^{W} \boldsymbol{R}_{V} & 0 \\
0 & { }^{W} \boldsymbol{R}_{V}{ }^{V} \boldsymbol{T}_{H}
\end{array}\right] V \boldsymbol{J}_{H}(\boldsymbol{q})
$$

となる.つまり移動ロボットの位置・姿勢推定誤差が発 生する作業座標系の方向についてはカメラフィードバッ クによる制御を行い, その他の方向については位置・姿 勢フィードバックで制御する. 以上の制御系のブロック 図を Fig. 10(a) に示す.

移動ロボットを床に固定し，偏差を検出するカメラセ ンサーをカセンサーに置き換え，力偏差を ${ }^{W} J_{H}{ }^{T}$ を用い てフィードバックすると，(26）式で表される制御系は, Fig. 10(b) に示す制御系となる. ${ }^{W} \boldsymbol{r}_{V}=\mathbf{0},{ }^{W} \boldsymbol{R}_{V}=\boldsymbol{I}$, $\boldsymbol{K}_{2}=\mathbf{0}$ と仮定して Fig. 10（a）を見直すと分かりやすい. Raibert らが提案した力・位置のハイブリッド制御系 ${ }^{14)}$ と Fig. 10(b) の制御系の違いは，制御モードを作業対 象物に設定した拘束座標系について割り振るか作業座標 系について割り振るかの違い，また制御出力がトルクで なく速度電圧であるといら違いがある。しかし，外界に 定義した座標系の基底方向に制御モードを割り付けると いう基本的な考えは同じである.

\section{7. 移動ロボットの位置・姿勢推定 誤差補償実験}

\section{1 ある万向には制御しない実験}

カメラフィードバックによる制御方向と運動学計算に 基づく制御方向が $\sum w$ の指定した方向で， $\boldsymbol{S}$ により分離 されていることを確認するために次のような実験を行っ た（26）式において， $\boldsymbol{K}_{1}$ は前実験と同じゲインとし， $\boldsymbol{K}_{3}=\boldsymbol{K}_{2}=\mathbf{0}$ と設定した. そして, $\boldsymbol{S}=\operatorname{diag}(0,1,0,0,0,0)$ と定めると， $\boldsymbol{e}_{P Y}$ につてはフィードバックがないので $\sum w$ の $y$ 軸方向には制御を行わない制御系となる．移動 


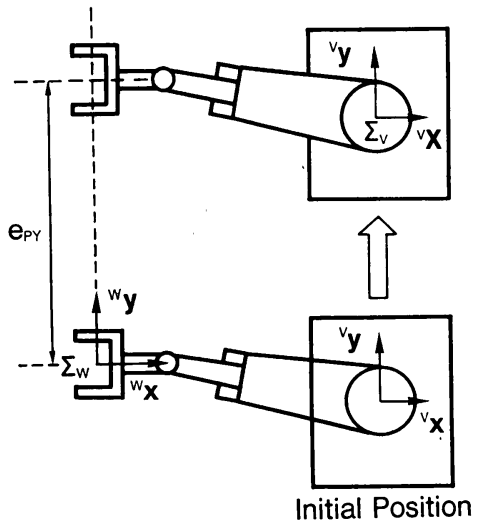

Fig. 11(a) Control result with straight traveling
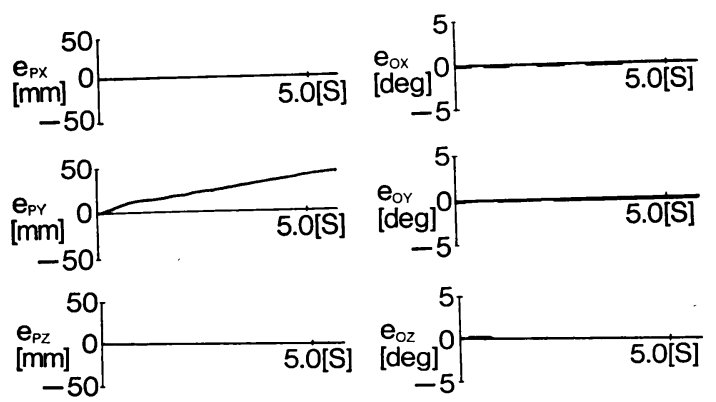

Fig. 11(b) Position and orientation errors (with no control in concerning with $y$ axis)

ロボットを $7 \mathrm{~mm} / \mathrm{s}$ の速度で $\sum w$ の $y$ 軸方向に走行さ せた制御結果を Fig. 11(b) に示す. 移動ロボットの走 行にともなって， $e_{P Y}$ のみ増加している.

次に，移動ロボットを $0.26 \mathrm{rad} / \mathrm{s}$ でスピンターンさ せ，前実験と同様に ${ }^{W} e$ を調べた．結果を Fig. 12(a)， (b) に示す. 前実験と同様に $e_{P Y}$ のみ增加し, 他の誤 差はほぼぜ口に制御されていることがわかる．以上の実 験により(26)式の右辺第一項による制御を行うとき の指定した方向のみ制御しない制御系となっていること がわかる.

\section{2 カメラフィードバックを付加した実験}

$\sum$ W の原点にマニピュレータのハンドで把持すべき対 象物を固き，これをハンドにとりつけたカメラで検出す る. $S=\operatorname{diag}(1,1,0,0,0,0), K_{1}, K_{2}$ の值は 5 章の実験 と同しにままた $\boldsymbol{K}_{3}=\operatorname{diag}(1,1,1,1,1,1)$ [Volt $\left./ \mathrm{rad}\right]$ と設定し $\sum_{W}$ の $x-y$ 平面内の誤差をカメラからの> イードヘックにより取り除く制御系とした. カメラセン サーからは $50 \mathrm{~ms}$ 周期で作業対象物の重心位置が出力さ れる. Fig. 7(a) に示した初期位固・姿勢をとらせ， $w^{\delta} \boldsymbol{x}=[100,-100,0,0,0,0]^{T}$ を移動ロボットの位 直 - 姿勢推定誤差に起因寸る誤差として意四的に与えた.

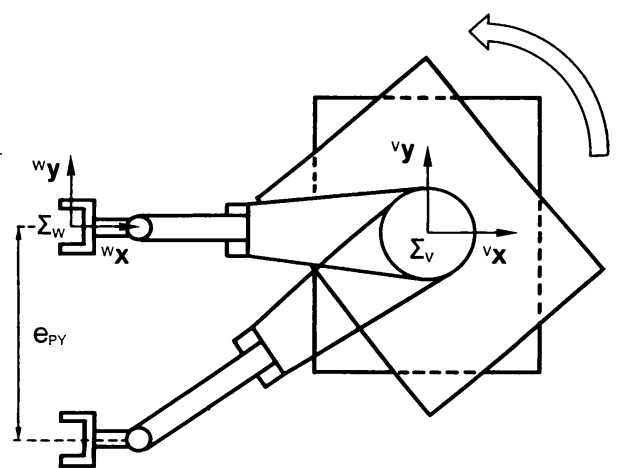

Fig. 12(a) Control result with spin traveling
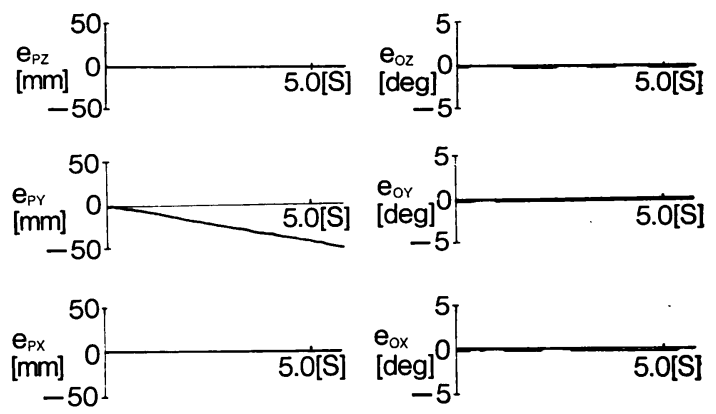

Fig. 12(b) Position and orientation errors (with no control in concerning with $y$ axis)

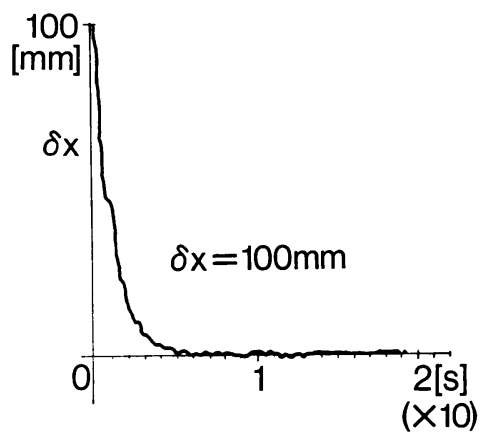

Fig. 13(a) Stop response result to compensate the estimated error ( $\mathrm{X}$-axis direction)

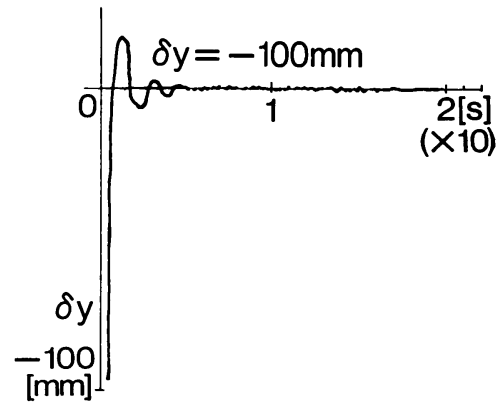

Fig. 13(b) Stop response result to compensate the estimated error ( $\mathrm{Y}$-axis direction) 
このときカメラの画像は Fig. 9 のようになる. 目標位 置・姿勢が一定值であるから ${ }^{W} \dot{\boldsymbol{r}}_{H d}=0$ であり，移動口 ボットを停止させて実験を行ったので，(14), (16), (18) より， $\dot{\boldsymbol{q}}_{d}=0$ であるから (26) 式の右辺第二項は働かな い.カメラからフィードバックされた $x, y$ 軸方向の偏 差の時間経過を Fig. 13(a ), (b ) 飞示す. $x$ 軸方向は 5 秒, $y$ 軸方向は 3 秒添どで 0 亿整定して拈り, 移動口 ボットの位置・姿勢推定誤差を車載マニピュレータが補 償する制御系となっていることがわかる。

\section{8.あとがき}

本論文は, 自律型移動ロボットにマニピュレータを搭 載し，走行しつつ搬送物の載脱荷作業をするための制御 系を提案し，実験によりその基本的な性能を確認したも のである. 提案した内容は次の点にまとめられる.

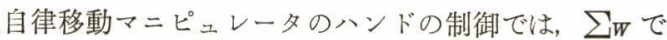
表された移動ロボットの推定䛊差を車載マニピュレータ の制御系が補償する必要がある．推定䛊差が発生する作 業座標系の方向にはカメラフィードバックを行い, その 他の方向については位置・姿勢フィードベックを行ら制 御系とを組及合わせた制御系を提案し，有効に働くこと を実験によって確認した．この力法は，双方の制御出力 が干啮しないよう分離する必要が生じ, 位置と力の八イ ブリッド制御13)で用いられているスイッチング行列を使 用して，作業座標系で表された制御方向を分けている.

本報で提案した制御系はダイナミクスを考慮したもの ではなく、また制御系の安定性については全く考察して いないが，今後取り組んで行きたいと考光ている.

\section{参考 文 献}

1) P.E. Muir, C.P. Neuman : Kinematic Modeling for Feedback Control of an Omnidirectional Wheeled Mobile Robot, Proc. IEEE Int Conf Rob Autom. pp. 1772-1778, 1987.

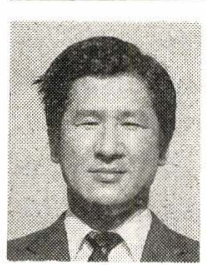

\section{見浪 護 (Mamoru MINAMI)}

1956 年 4 月 25 日生. 1981 年大阪府立大 学航空工学科修士課程修了. 同年(株)椿本 チェイン入社. 研究開発部勤務. 1990年金 沢大学工学部博士課程入学, 現在在学中. 自動搬送車の開発, 移動ロボット, 移動マ ニュピレータの研究に従事.

(日本ロボット学会正会員)

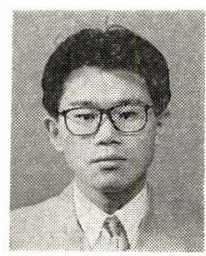

\section{柘植広志 (Hiroshi TSUGE)}

1967 年 6 月 5 日生. 1990 年金沢大学工 学部生産精密工学科卒業. 1992年同大学院 修士課程修了, 同年豊田自動織機製作所入 社.

\footnotetext{
（日本ロボット学会正会員）
}

2) P.F.Muir, C.P. Neuman : Kinematic Modeling of Wheeled Mobile Robots, Journal of Robotic Systems, pp. 281-340, 1987.

3）見浪，篻，上田，中野：同時変換を用いた自律型移動口 ポットの任意曲線コース誘導方法, 日本ロボット学会誌, Vol.8, No.4, pp.421-430, 1990.

4）築島, 高野, 佐々木, 井上 : 車輪式移動ロボットの運動 学および動力学の一般理論に関する研究, 日本ロボット 学会誌, Vol 8, No.6, pp.699-711, 1990.

5) Kanayama, Y., Kimura, Y.,Miyazaki, F., and Noguchi, T.: A stable tracking control method for an autonomous mobile robot, Proc. 1990 IEEE International Conference on Robotics and Automation, pp. 384-389, 1990.

6) 中村, シュリカン サパント：海中ロボットの非ホロノ ミック運動, 日本ロボット学会講演論文集, pp. 805-808, 1991.

7）見浪, 冨川, 箭 : 磁石補償式自律誘導方法, システムと 制御, Vol.31, No.5, pp. 382-391, 1987.

8）津村，藤原，白川，唐：レーザ燈台を用いた二次元移動 体の位置・方位測定法, システムと制御, Vol.29, No. 3, pp. 188-194, 1985.

9）津村，藤原，白川，田中：レーザとコーナキューブを利 用した二次元移動体の位置・方位測定法，システムと制 御, Vol.29, No.8, pp. 553-560, 1985.

10）津村, 藤原, 橋本, 唐：レーザ登台を用いた移動体の位 置・方位測定法, 日本ロボット学会誌, Vol.2, No.6, 6, pp. 557-565, 1984.

11）津村, 藤原, 橋本, 唐 : 追尾式レーザ燈台を用いた二次 元移動体の位置測定法, 日本ロボット学会誌, Vol.3, No. 6, pp. 521-530, 1985.

12）津村, 藤原, 白川, 岡崎 : 移動体の現在位習·進行方位 の計測の一方法, 日本機械学会論文集 C編, Vol.47, No.421, pp. 1153-1160, 1984.

13) J.Y. Luh, M.W. Walker, R.P. Paul : Resolved acceleration control of mechanical manipulators", IEEE Trans. Automatic Control, 25, pp.468-474, 1980.

14) W. H. Raibert and J. J. Craig : Hibrid position/force control of manipulators, ASME J. of Dynamic Systems, Measurement, and Control 104, No.1, pp. 65-77, 1981.

15）有本卓著: “ロボットの力学と制御”, 朝會書店, 1990.

\section{藤原直史}

(Naofumi FUJIWARA)

1942年11月22日生. 1965年 3 月大阪府立 大学工学部航空工学科卒業. 1965年 4 月大 阪府立大学助手として勤務. 1989年 4 月金 沢大学教授 (機械システム工学科) 現在に 至る. 移動体の位置計測, 誘導に関する研 究に從事. 日本機械学会, 計測自動制御学会, システム制御情 報学会, ピークルオートメーション技術研究会会員・

（日本ロボット学会正会員） 